\title{
Fibrinogen Alpha Chain
}

National Cancer Institute

\section{Source}

National Cancer Institute. Fibrinogen Alpha Chain. NCI Thesaurus. Code C150231.

Fibrinogen alpha chain ( $866 \mathrm{aa}, \sim 95 \mathrm{kDa}$ ) is encoded by the human FGA gene. This protein is involved in blood clot formation. 